\title{
Must-reads for Copenhagen
}

\author{
MIKE HULME, TONY JUNIPER, MARK LYNAS, OLIVER MORTON, RON OXBURGH, \\ RAJENDRA K. PACHAURI, ROGER PIELKE, JR, ANDREW REVKIN AND JOSEPH ROMM
}

\begin{abstract}
At the UN Climate Conference in Copenhagen this December, talk will turn to scientific, political and economic issues with a global reach and a long history — not easy to pick up from the daily news. We asked select experts on climate change what books we should be reading ahead of the big event.
\end{abstract}

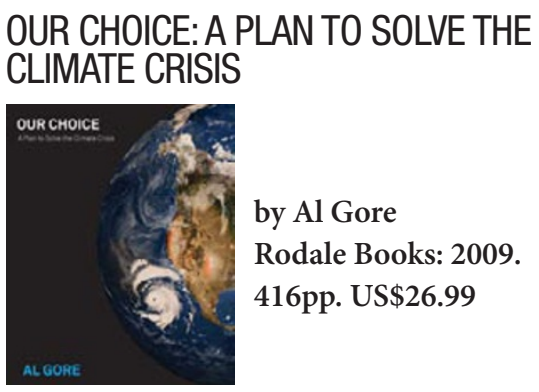

Joseph Romm, Center for American Progress: When your last work led to an Oscar and Nobel Prize, anticipation is high on the sequel. And former US Vice President Al Gore's new book delivers. Our Choice, due out in November, is a wonderfully readable treatise on climate solutions.

Whereas An Inconvenient Truth framed the crisis that climate negotiations are tackling, this followup spells out what needs to be done. Based on 30 of Gore's 'Solutions Summits' as well as one-on-one discussions with leading experts across multiple disciplines, the book aims, in Gore's words, "to gather in one place all of the most effective solutions that are available now". Gore naturally focuses on energy, the source of most anthropogenic greenhouse gas emissions, and discusses many underappreciated strategies such as concentrated solar thermal power and cogeneration. He also devotes a full chapter to soil, a major carbon sink that is gradually degrading. Farming strategies for restoring soil carbon are described, including biochar, a porous charcoal that can potentially enhance the soil sink while providing a source of low-carbon power. And like its PowerPoint-based predecessor, Our Choice is replete with lush photos and simple but powerful charts. This a must-read book for those who want a primer on all the key solutions countries will be considering at Copenhagen.

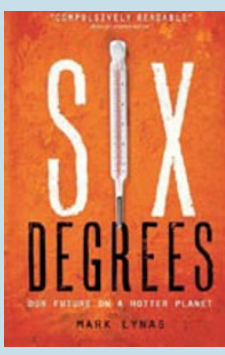

Tony Juniper, campaigner and former director of Friends of the Earth: Allowing the average global temperature to rise more than $2{ }^{\circ} \mathrm{C}$ above its pre-industrial level would be the gravest crime in history. To understand why, climate negotiators - and the ministers who issue their instructions - should read Six Degrees.

The recent climate science tells us that up to $6{ }^{\circ} \mathrm{C}$ of warming above preindustrial temperatures is possible by 2100 if we continue on our current emissions path. Journalist Mark Lynas's accessible book draws on both future projections and evidence from the past to paint a vivid picture of the changes we can expect with each degree of warming. Six Degrees reveals the practical implications of the different emissions reduction pathways that will be argued over in Copenhagen.

With $3^{\circ} \mathrm{C}$ of warming, massive feedbacks would occur, rainforest would die back and major rivers would be lost, causing vast economic damage and human suffering. At $4{ }^{\circ} \mathrm{C}$, a very different world would emerge, and it would not be conducive to the maintenance of secure economic and social conditions. Unfortunately, this is the expected outcome from modest emissions cuts, presuming they are actually delivered. Policymakers will have to forge a highly ambitious deal to avoid the crisis.

\section{CHALLENGED BY CARBON: THE OIL INDUSTRY AND CLIMATE CHANGE}

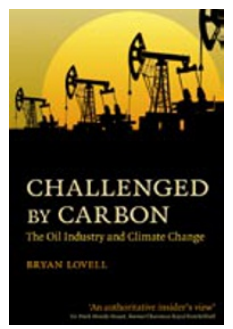

by Bryan Lovell Cambridge University Press: 2009.

208pp. $£ 55.00$

Ron Oxburgh, UK House of Lords and former chairman of Shell: 'Climate change fatigue' is said to be an ailment slowly spreading through the media. As
Copenhagen takes over the headlines, Bryan Lovell's lively new book - peering into the doubts, concerns and prejudices that have dogged climate negotiators - is an instant tonic for this malady.

Lovell, whose career has spanned geological academia and the petroleum industry, gives an eyewitness account of oil producers' shifting views on global warming. Unlike many writers on climate, he presents today's changes in their longterm geological context and shows how this had impeded understanding of human influences. After all, the argument went, the climate has changed many times in the past, so what is different today? Lacing 
the story with personal anecdotes, Lovell describes a slow evolution in the industry from scepticism and hostility to a widespread if not universal recognition that although coal is the main culprit, burning oil is a major and growing contributor to climate change. He concludes with a practical discussion of how to make the transition to a different world. Challenged by Carbon is a good read that the nonspecialist will find refreshingly free from technical jargon and that all will find rich with the insider history behind December's talks.

SEEING LIKE A STATE: HOW CERTAIN SCHEMES TO IMPROVE THE HUMAN CONDITION HAVE FAILED

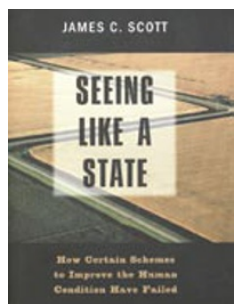

by James C. Scott Yale University Press: 1999 (originally published 1998).

464pp. US $\$ 21.00$

Roger Pielke, Jr, University of Colorado at Boulder: The painful truth is that no one knows how to decarbonize the global economy. Unrealistic commitments to targets and timetables for emissions reductions under an ever more complex superstructure of international bureaucracy cannot succeed. This is more than common sense - it's a lesson of history, as explored in James Scott's 1998 book Seeing Like a State.

Scott, a political scientist, recites a litany of failed attempts at centralized planning that should serve as warnings to Copenhagen. In each case planners failed because the real world turned out to be far more complex than even the most complicated schemata invented to manage it. Scott warns that the "mechanical application of generic rules" - such as emissions targets in climate policy - "is an invitation to practical failure, social disillusionment, or most likely both". He proposes that, instead of convoluted centralized plans to remake society, we recognize the need for practical wisdom embodied in conceptions of 'muddling through'.

We will muddle through on climate policy whether we like it or not. We could choose to do so deliberately, with realistic, short-term targets for improving energy efficiency and decarbonizing energy supply that can be re-evaluated as experience accumulates. The alternative is to add yet another lesson to the list of impressive failures of central planning.
KYOTO2: HOW TO MANAGE THE GLOBAL GREENHOUSE

\section{Kyoto2}

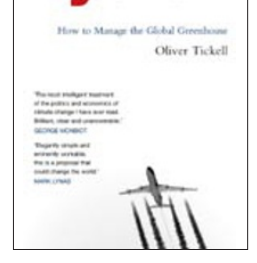

by Oliver Tickell

Zed Books: 2008.

301pp. £39.99

Mark Lynas, environmentalist and author of Six Degrees: Imagine we were a sensible species. Intelligent and thoughtful, as our name sapiens suggests. What would be the most rational approach to our greenhouse gas problem? The options on the table for Copenhagen get just about everything wrong, according to environmental campaigner Oliver Tickell, in his fascinating book Kyoto2.

For a start, he says, regulating emissions is a losing game. Are we really going to try to police the carbon burned by close to 7 billion individuals? A better option, Tickell suggests, is to regulate production by setting a global cap on the amount of carbon being drilled, dug and piped out of the ground. Don't work with individuals or even governments: auction carbon production rights to companies instead. There are then only a few hundred agents, not a few billion, to worry about. And instead of fighting over who has to make emissions cuts, fight over which countries get the auction cash.

All in all, the Kyoto2 proposal is just the thing a truly sapient species would come up with. As governments head grimly into negotiations determined to avoid a policy failure, it's worth keeping in mind that the system they're hashing out is not the only possible one or even the best.

\section{WHY WE DISAGREE ABOUT CLIMATE CHANGE: UNDERSTANDING CONTROVERSY, INACTION AND OPPORTUNITY}

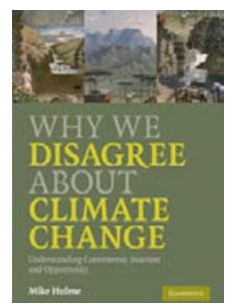

by Mike Hulme

Cambridge University Press: 2009.

432pp. $£ 45.00$

Andrew Revkin, The New York Times:

Can we 'solve the climate crisis' in the same way twentieth-century pollution problems were addressed? Mike Hulme, a seasoned climate scientist who has dived deeply into the policy arena and social sciences, says this presumption hides an uncomfortable reality that is snarling international policymaking.

In Why We Disagree About Climate

Change, Hulme asserts that "climate change is not 'a problem' waiting for 'a solution"' but rather is an idea whose shape can differ completely depending on one's political and cultural biases. The book implies strongly that the deep divisions among the variegated parties coming together in Copenhagen - deeply poor countries, fastgrowing giants, established powers - are unlikely to be easily bridged in a single accord. Each faction has, in essence, a unique definition of the climate challenge: for the poorest, it's about adaptation and equity; for the richest, it's about energy technology and markets; for the forested, it's about credit for carbon stores. Hulme's argument bolsters predictions by long-time observers of climate diplomacy that a grand agreement is less achievable than a set of specific deals on particular issues.

\section{THE SUSTAINABILITY MIRAGE: ILLUSION AND REALITY IN THE COMING WAR ON CLIMATE CHANGE}

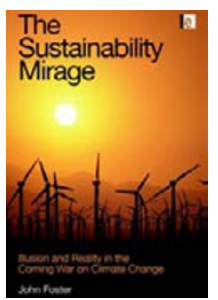

by John Foster

Earthscan Ltd: 2008.

190pp. $£ 70.00$

Mike Hulme, University of East Anglia: Beyond the frequently invoked battle-line between climate change 'believers' and 'sceptics', there is a deeper, and in the end more important, division of thinking. This more fundamental battle-line, revealed by environmental philosopher John Foster in his book The Sustainability Mirage, is between those who believe that techno-fixes, market instruments and political agreements - at Copenhagen or elsewhere - can contain the risks of climate change, and those who read climate change as a parable about human individuals and societies seeking ever greater material affluence while ignoring their interior worlds. In Foster's terms, UN negotiators and others living by 'extrinsic values' are divided from those who emphasize 'intrinsic values'.

This is a challenging book that explores some crucial social and psychological realities of climate change. Foster engages with the deepening tension that humans face, living in the overconsuming present while being aware of the unrepresented future. He honestly reveals some of the structural limitations of the sustainable-development paradigm and struggles with interpreting 
the value-action gap that all of us, to varying degrees, encounter in our behaviour. But you won't hear too much about this during the Copenhagen conference. So read it.

\section{WHOLE EARTH DISCIPLINE: AN ECOPRAGMATIST MANIFESTO}

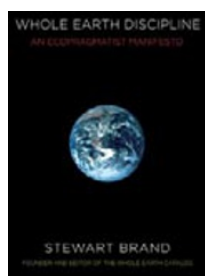

Stewart Brand

Viking Adult: 2009.

336pp. US\$25.95

Oliver Morton, until recently chief news and features editor, Nature: This book is not going to help anyone get to grips with the intricacies of the UN climate negotiations, but if you want to lift your head from the trenches for an overview of the twenty-first century, it's a great place to start. Brand has been championing clear long-term visions since he campaigned for NASA to photograph the Earth from space in the 1960s, later setting up such farsighted institutions as the Whole Earth Catalog, the Global Business Network and the Long Now Foundation.
His new book, though presented in small chunks that are enticing to skip in and out of, nevertheless builds up into a lucid big picture put together with experience, wisdom and optimism. Brand tackles touchy issues such as the importance of urbanization, the potential of genetic engineering and the practical case for nuclear power, fully aware that many of the environmentalist readers he hopes to reach will start out disagreeing with him. He refuses either to pander to their prejudices or to take delight in shocking them, preferring engagement, reason and a leavening of wit. He simply argues persuasively, on the basis of wide reading, for the positions he thinks will best allow humans to shore up nature so that nature in turn can help preserve humanity.

\section{CLIMATE CHANGE 2007: SYNTHESIS REPORT}

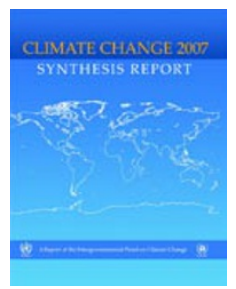

Edited by the IPCC Core Writing Team, Rajendra K. Pachauri and Andy Reisinger IPCC: 2007. 104pp.
Rajendra K. Pachauri, chairman, Intergovernmental Panel on Climate Change (IPCC): The Synthesis Report, part of the IPCC's Fourth Assessment Report, is a unique document that should top the reading list of anyone trying to understand the scale of the climate challenge.

Released in November 2007, it bridges the worlds of scientific analysis and policy options in a way that is effective and scientifically robust but readable and easily understood. It has perhaps been the IPCC's most effective report thus far in creating awareness among leaders of every section of society, as well as among society at large.

The report presents the robust scientific evidence of climate change, the projection of future impacts and the economic attractiveness and technical feasibility of available and projected mitigation options. In essence, it clearly maps out the serious consequences of inaction, as well as the feasibility and affordability of action both to adapt to the impacts of climate change and to mitigate emissions of greenhouse gases.

Published online: 2 October 2009

doi:10.1038/climate.2009.102

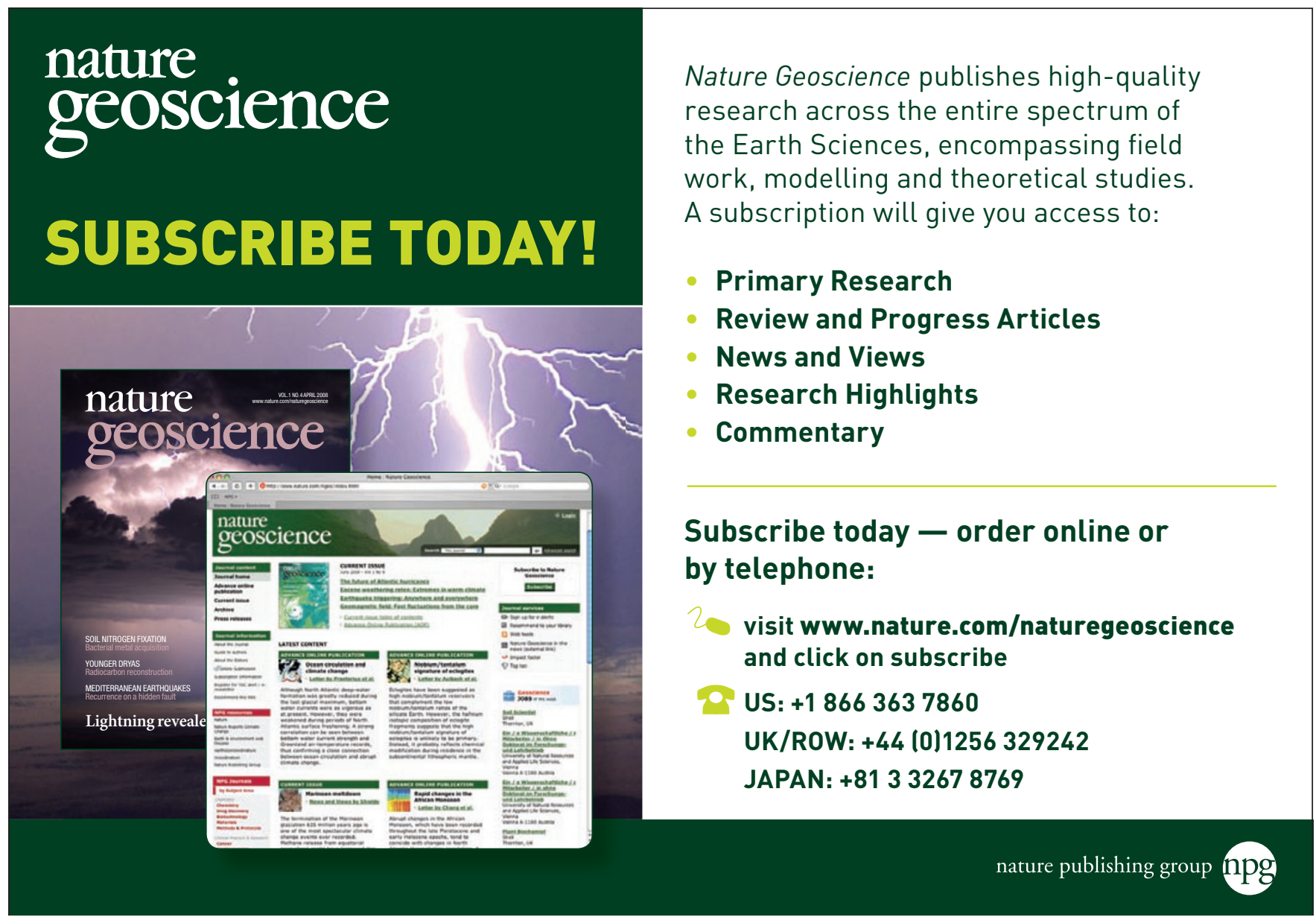

